$$
19-27621
$$




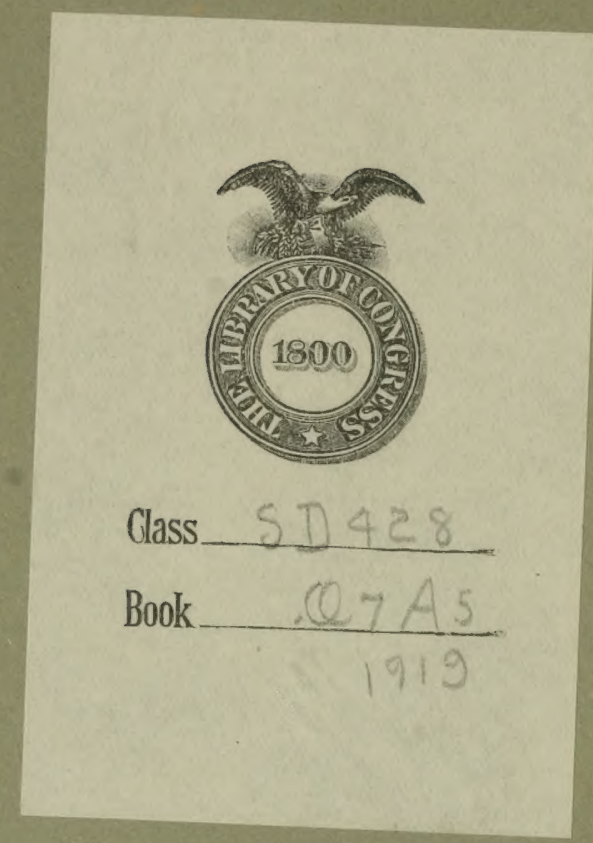




\section{ADDITIONS TO OREGON, SIUSLAW, AND CRATER NATIONAL FORESTS, OREG.}

Oстовеr 28, 1919.-Committed to the Committee of the Whole House on the state of the Union and ordered to be printed.

Mr. Sinnotr, from the Committee on the Public Lands, submitted the following

\section{REPORT.}

[To accompany H. R. 8028.]

The Committee on the Public Lands, to whom was referred the bill (H. R. 8028) to add to the Oregon, Siuslaw and Crater National Forests in Oregon certain tracts of lands for the protection of the water supply of the cities of Ashland, Corvallis, Dallas, and Oregon City, having carefully considered the same, report the bill back to the House, with certain amendments, with the recommendation that as amended the bill do pass.

The committee offered the following amendments:

On page 2, line 7, after the word "Forests" insert the following: "subject to all laws affecting national forests."

On page 3, line 17, strike out the words "Forest Service, Department" and insert in lieu thereof the word "Secretary."

On page 3, line 20, strike out the words "Forest Service" and insert in lieu thereof the word "Secretary."

On page 3, line 18, strike out the word "sold" and insert in lieu thereof the word "cut."

On page 3 , line 21 , strike out the words "sell and," also the words "to the highest bidder."

In the title of said bill, in line 1, strike out the words "reserve as parts of" and insert in lieu thereof the words "add to."

In the last line of said title, change the period following the word "States" to a comma and add the following words: "and for other purposes."

The lands which it is proposed to add to these national forests are small areas of the lands formerly granted to the Oregon \& California Railroad Co., but which were revested in the United States by an 
act of Congress approved June 9, 1916 (39 Stat. L., 218-223), pursuant to a decision of the Supreme Court of the United States rendered June 21, 1915 (238 U. S., 303-439).

The cities mentioned in the bill own their water systems, and have constructed pipe lines of considerable length to the intakes in the mountains from which their water supplies are derived, in order to obtain an adequate quantity of pure water for the use of their citizens. Each city is confined to its present source of supply for the reason that there is no other source from which it can secure water from mountain streams. The lands which the bill proposes to add to the natural forests are intermingled with other lands from which they obtain water, and are absolutely necessary in order to provide an adequate amount of pure water. These lands are largely forested. If they are cut over and burned over, as a natural consequence the water supplies will become contaminated, the quantity now available during the summer seasons will be greatly reduced, and the regularity of flow will be seriously impaired; instead of being stored in the mountains for summer use, as it now is, by percolation into natural reservoirs, if the natural forest cover is destroyed, the precipitation will run rapidly from the areas deprived of such cover and be wasted. Some of the cities, and especially Corvallis, the seat of the Oregon Agricultural College, suffer now from a scarcity of water in unusually dry summers.

These cities have made municipal improvements, including paving, construction of sewers and of the water systems, and for other municipal purposes, and have issued bonds to provide payment therefor to such an extent that they have practically reached the legal limit of indebtedness, and for the present are not in a position to purchase these lands.

There is precedent for this action. One precedent arises in connection with these same Oregon \& California lands. Congress passed an act approved October 21, 1918, by which it added to the Oregon National Forest an area of about 11,000 acres, which largely exceeds the total of the areas described in this bill, for the protection of the water supply of the city of Portland, Oreg. (40 Stat. L., 1015.)

The Secretary of Agriculture submitted in connection with that transfer the following report:

\section{Department of Agriculture,}

Washington, August 5, 1918.

Hon. SCOTT FERris,

Chairman Committee on Public Lands, House of Representatives.

Dear Mr. Ferris: Receipt is acknowledged of a copy of the bill H. R. 6971, "To reserve as a part of the Oregon National Forest certain lands that were revested in the United States pursuant to the decision of the Supreme Court of the United States in the case of the Oregon \& California Railroad Co. against the United States," together with a letter to you from Hon. C. N. McArthur and a report upon the measure made by the Secretary of the Interior. In your letter you request that this department send such suggestion as it may desire to make.

As indicated by its title, the bill proposes that somewhat less than 11,000 acres of lands formerly granted the Oregon \& California Railroad Co., and which have become revested in the United States, be made a part of the Oregon National Forest. In the report made by the Interior Department it is shown that the purpose of this addition is to help preserve the purity of the water used by the municipality of Portland, Oreg.

About 30 years ago the officials and citizens of the city of Portland, realizing the importance of protecting the watershed used by the municipality, sought to have approximately six townships in what is now the Oregon National Forest reserved from entry-and disposition. This embraced the land through which the Bull Run

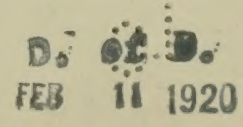


River and its tributaries extends from Bull Run Lake close to the Cascade Divide, westerly toward the city of Portland. This effort resulted in the proclamation of June 17, 1892, which established this area as the Bull Run Forest Reserve. In an endeavor to grant further protection to this area Congress passed the act of April 28, 1904 (33 Stat., 526), which prohibits grazing and trespass upon the Bull Run area and excludes all persons therefrom, except forest officers and Federal and State officials, and employees of the Portland water board in the discharge of their duties.

Prior to the reservation of this land in 1892 the Oregon \& California Railroad Co. made selections in what is now the Bull Run area of alternate sections of land. These, as stated by the Secretary of the Interior, comprise 10,760.73 acres. Checkerboard fashion, they extend over much of the eastern point of the Bull Run Reservation and lie, for the most part, on the Bull Run drainage. Prior to the passage of the act of June 9, 1916 (39 Stat., 218), which revested them in the Government, title to these areas was in the railroad company. While the lands were in railroad ownership neither this department nor the city officials had any jurisdiction whatever to administer them. They therefore presented an opportunity for contamination of the watershed, which could not be prevented except through the courtesy of the railroad.

The city officials of Portland have always jealously guarded this watershed to prevent pollution of the water supply, and this department has given every possible aid in protecting and administering the Bull Run watershed, recognizing always that the highest use of these lands was for municipal watershed purposes. While all parts of these O. \& C. lands are not directly on the drainage of the Bull Run River, their administration in connection with the watershed is highly essential. Without it, adequate protection from fire or use could not be maintained. Furthermore, in addition to the lands which lie on the watershed of Bull Run River, some of them are on the drainage of the Little Sandy River. Although at the present time the Portland city water supply is obtained wholly from Bull Run River, it is understood that more comprehensive plans are contemplated by the city officials which will take in the waters from the Little Sandy. To permit any of these lands to be disposed of under the terms of the act of June 9,1916 , would no doubt interfere with the city's plan for a permanent future water supply.

For the most part these lands are rough and mountainous, too steep for cultivation, and their principal use will always be for timber production or watershed protection. They are similar in this respect to the other lands within the Bull Run Reservation. This department feels that all of the railroad lands within the Bull Run area, which have become revested in the United States, should be added to the forest as a measure of protection for the water supply of the city of Portland, and therefore approves the bill in its present form.

Very truly, yours,

D. F. Houston, Secretary.

This committee reported favorably on a similar bill, H. R. 12770, in the third session of the Sixty-fifth Congress on January 2, 1919, Report No. 883. The pending bill differs from the former bill only in the inclusion of provision for the city of Ashland, and in a slightly different arrangement in the interest of clearness.

The Secretaries of Interior and Agriculture have submitted favorable reports upon the measure, and on the measures pending in the preceding Congress for the same purpose, as follows:

\section{DEPARTMENT OF THE INTERIOR,}

Washington, August 21, 1919.

Hon. N. J. Sinnotr,

Chairman Committee on the Public Lands,

House of Representatives.

My Dear Mr. Sinnotr: In response to your request therefor, report is made on H. R. 8028, as follows:

Said bill, entitled "A bill to reserve as parts of the Oregon, Siuslaw, and Crater National Forests in Oregon certain lands that were revested in the United States pursuant to the decision of the Supreme Court in the case of the Oregon ano California Railroad Company against the United States," proposes to add to said forests certain lands described therein for the conservation and protection of the water supplies of the cities of Oregon City, Dallas, Corvallis, and Ashland, Oreg., which are within the limits of the grant by the United States to the Oregon \& California Kailroad Co., and the title to which was revested in the United States by the act of June 9, 1916 (39 Stat., 218). 
The tracts described in the bill which are proposed to be reserved for the benefit of Oregon City, Dallas, and Corvallis were the subject of legislation proposed in H. R. 12770, Sixty-fifth Congress, upon which a report was made by me October 4, 1918, recommending the approval of the bill upon its amendment as therein indicated. A copy of said report is hereto attached. The tracts described in the bill which are proposed to be reserved for the benefit of the city of Ashland, Oreg., were the subject of legislation proposed in H. R. 11550, Sixty-fifth Congress, upon which a report was made by me January 11,1919 , in which it was stated that with the amendments suggested the bill met with my approval. A copy of said report of January 11, 1919, is also attached.

In addition to the data contained in said reports as to the status of the lands described therein, I am informed that the records of the General Land Office show that the SE. $\frac{1}{4}$ of sec. 33 , T. 7 S., R. $6 \mathrm{~W}$., proposed to be reserved for the benefit of the city of Dallas, is included in water-power designation No. 14 by departmental order dated December 12, 1917, and was included in power-site reserve No. 661 by Executive order dated Derember 12,1917 . The NE. $\frac{1}{1}$, N. $\frac{1}{2}$ NW. $\frac{1}{4}$ sec. 19 , NE. $\frac{1}{4}$ sec. 27, NW. $\frac{1}{4}$ NW. $\frac{1}{4}$, S. $\frac{1}{2}$ NW. $\frac{1}{4}$, S. $\frac{1}{2}$ NE. $\frac{1}{4}$ sec. 29 , and SE. $\frac{1}{4}$ NW. $\frac{1}{4}$, E. $\frac{1}{2}$ SW. $\frac{1}{1}$, and E. $\frac{1}{2}$ sec. 31 , T. 4 S., R. 5 E., were included in water-power designation No. 14 by departmental order dated December 12, 1917, but have not been formally included in a power-site reserve.

It is further shown that H. R. 12770 was reported upon favorably on January 2, 1919, by the Committee on the Public Lands, with certain suggestion amendments, and ordered printed. So far as the records of this department show, no action was taken on H. R. 11550.

The bill now under consideration, H. R. 8028, is a consolidation of the provisions of said H. R. 12770 and 11550 and embodies all the amendments to the former bills suggested by the Secretary of Agriculture and by me. Having in mind the purposes intended to be served by the proposed legislation, I would recommend the same to your favorable consideration.

Cordially, yours,

\section{F. K, LANE, Secretary.}

\section{DEPARTMENT OF THE INTERIOR,} Washington, January 11, 1919.

Hon. SCOTT FERRIS,

Chairman Committee on the Public Lands,

House of Representatives.

Mr Dear Mr_Ferris: In response to your request therefor report is made on $H$. $R$. 11550 as follows:

Said bill, entitled "A bill to reserve as part of the Crater National Forest in Oregon certain lands formerly a part of the grant to the Oregon and California Railroad Company but revested in the United States in accurdance with a decision of the Supreme Court of the United States recorded in two hundred and thirty-eighth United States Reports, page 393," proposes to add to the Crater National Forest the tracts of land therein described for the protection of the water supply of the city of Ashland, Oreg.

The records of the General Land Office show that the tracts described, the E. sec. 19 , E. $\frac{1}{2} \mathrm{NW}, \frac{1}{1}$, E. $\frac{1}{2} \mathrm{SW} . \frac{1}{4}$, and E $\frac{1}{3}$ sec. 21 , T. $39 \mathrm{~S}$., R. 1 E., Willamette meridian, Oregon, were patented to the Oregon \& California Railroad Co. under its grant by the act of July 25, 1866 (14 Stat, 239), and title thereto was revested in the United States under the provisions of the act of June 9, 1916 (39 Stat., 218).

All of the tracts revested in the United States were classified as agricultural except the SE. $\frac{1}{4}$ NE. $\frac{1}{4}$ and S. $\frac{1}{2}$ SE. $\frac{1}{4}$ sec. 19 , which were reported as containing more than 300,000 feet board measure of timber on each 40-acre subdivision, and were therefore classified as timberland. There is some timber on the subdivisions classified as agricultural, less than 300,000 feet board measure on each 40 -acre subdivision, which is reported by the cruisers as being valuable only for posts and cordwood. It is further shown that the tracts immediately adjoin the exterior limits of said Crater National Forest in said township.

It also appears from data available in the General Land Office that these tracts are located on or immediately adjacent to Ashland Creek and its tributaries 2 or 3 miles from the city of Ashland and are valuable for watershed protection purposes. It would therefore seem to be advisable that they should not be permitted to pass into private ownership under the provisions of said act of June 9, 1916, and I would therefore interpose no objection to the reservation proposed by said bil!. In this connection, however, attention is directed to the fact that the Government must under the 
provisions of the act of June 9,1916, reimburse the railroad company at the rate of $\$ 2.50$ per acre for all the lands taken over by the United States thereunder, and that the reservation proposed, by withholding these lands and the timber thereon from disposition, will reduce the total proceeds to be received by the Government from the sales of such timber or lands prescribed for the revested area. It will also, in the event of a surplus remaining from such proceeds after the net amount due the railroad companv and the sum paid for accrued taxes have been deducted, necessarily reduce the portion of such surplus allotted to the State of Oregon, and materially that which Jackson County would receive, which is to be apportioned from the net amount of the proceeds from the sales of timber and lands, as well as the amounts to be credited from such surplus to the reclamation and general funds as provided in section 10 of said act.

For this reason I believe that the timber should be sold where it can be done withont material damage to the water supply and would therefore recommend that the bill be amended by adding thereto a section 2, reading as follows:

"SEc. 2. That when the Forest Service, Department of Agriculture, finds that merchantable timber may be sold from the above-described lands without detriment to the purity of or depletion of the water supply of A shland, said Forest Service is hereby authcrized to sell and dispose of to the highest bidder such merchantable timber on the lands added to said naticnal forest by section 1 hereof and the entire proceeds of such sale shall be deposited in the Treasury of the United States in a special find designated as 'The Oregon and California land-grant fund,' referred to in section 10 of the said act of June 9, 1916, and be disposed of in the manner therein designated: Provided, That in the event any of said lands are eliminated from said forest as not necessary for the purposes for which this reservation is made they shall be disposed of in the manner provided for by said act of June 9, 1916."

While no objections are interposed to the general purposes of the bill, the lands not necessary for the protection of the water supply of said city of Ashland should be excluded from the provisions thereof and be disposed of in the manner prescribed by said act of Jine 9, 1916. It is believed that the Forest Service, Department of Agriculture, will be in a position to advise your committee as to what portion, if any, of said lands is not necessary for the purposes named. As the administration of the national forest is under the jurisdiction of the Secretary of Agricultr re, I would therefore singgest a reference of the bill to him for specific information as to the area necessary for the proposed protection of the water supply of said city of Ashland and for such other recommendations as he may deem proper.

With the amendment above suggested the bill meets with my approval. Cordially, yours,

Alexander 'T. Vogersang, Acting Secretary.

\section{DepartMent OF THE INTERIOR,} Washington, October 4, 1918.

Hon. ScotT Ferris,

Chairman Committee on the Public Lands,

House of Representatives.

My Dear Mr. Ferris: In response to your request therefor, report is made upon H. R. 12770 as follows:

Said bill, entitled "A bill to reserve as part of the Oregon and Siuslaw National Forests in Oregon certain lands that were revested in the United States pursuant to the decision of the Supreme Court of the United States in the case of the Oregon and California Railroad Company against The United States," proposes to add to said forests certain lands therein described in order to prevent the depletion and contamination of the water supply of the cities of Corvallis, Dallas, and Oregon City, Oreg.

The records of the General Land Office show that the tracts described, aggregating in area 8,008.07 acres, were patented to the Oregon \& California Railroad Co. under its grant by the act of July 25, 1856 (14 Stat., 239), and title thereto was revested in the United States under the provisions of the act of June 9, 1916 (39 Stat., 218).

The tracts in T. 4 S., R. 5 E., are within the exterior limits of the Oregon National Forest, but were not affected by the various proclamations establishing said forest, for the reason that they were patented to the railroad company and therefore excepted from the terms of the proclamation establishing said forest reservation. The tracts in T. 5 S., R. 4 E., adjoin said Oregon National Forest on the west. The tracts in T. 7 S., R. 6 W., are about 11 miles east of the eastern line of the Siuslaw National Forest boundary, in T. 7 S., R. 8 W., and the tracts in T. 12 S., R. 7 W., are 8 miles east of the eastern boundary of said Siuslaw National Forest, in T. 12 S., R. 9 W. Willamette meridian, Oregon. 
The tracts in T. $4 \mathrm{~S}$., R. $5 \mathrm{E}$., have not yet been classified with respect to their value as timber or agricultural lands under the provisions of section 2 of said act of June 9,1916 , but the remainder of said lands, with the exception of a comparatively small number of tracts, have been classified as timberlands, each 40-acre subdivision or its equivalent containing 300,000 feet, board measure, or more of timber. The tracts which were not classitied as timberland are also shown to contain some timber, but it is not of a merchantable character. The reports of the examiners who classified the timbered lands show that they contain approximately $289,591,000$ feet, board measure, of merchantable timber. The lands described in said bill all form parts of the watershed of rivers from which the cities named derive their water supply, and it is urged that their inclusion in these forests is necessary in order to prevent pollution of the water supplies of these cities.

It would seem advisable that these lands, on account of their value for watershed protection purposes, should not be permitted to pass into private ownership, under the act of June 9, 1916, and I would, therefore, interpose no objection to the reservation proposed by said bill. In this connection, however, attention is directed to the fact that the Government must, under the provisions of said act of June 9, 1916, reimburse the railroad company at the rate of $\$ 2.50$ per acre for all of the lands taken over by the United States thereunder and that the reservations proposed by withholding these lands and the timber thereon from disposition will reduce the total proceeds to be received by the Government from the sales of such timber or lands prescribed for the revested area. It will also, in the event of a surplus remaining from such proceeds after the net amount due the railroad company and the sum paid for accrued taxes have been deducted, necessarily reduce the portion of such surplus allotted to the State of Oregon and materially that which the counties in which these lands are situated, namely, Clackamas, Polk, and Benton would receive, which is to be apportioned from the net amount of the proceeds from the sales of timber and lands in the respective counties as well as the amounts to be credited from such surplus to the reclamation and general funds as provided in section 10 of said act.

For this reason I believe that the timber should be sold where it can be done without material damage to the water supply. I believe that the language on page 3 , lines 5 , 6 , and 7 of section 2 where it states "after consultation with the water committees of the cities of Corvallis, Dallas, and Oregon City, all in the State of Oregon "and the works "of each" on line 9 of said page 3 should be eliminated, for either it means that the sales of timber can only be made with the approval of the city authorities of the cities named or it means nothing. Doubtless the Forest Service would in any case give due consideration to the purposes of the withdrawal in the disposition of the timber.

While no objections are interposed to the general purposes of the bill, I am not entirely satisfied that all the lands described should be added to and made a part of said forests. The lands included not necessary for the protection of the water supply of the cities named should be excluded from the provisions of this bill and disposed of in the manner prescribed by the act of June 9, 1915.

It is believed that the Forest Service, Department of Agriculture, will be in a position to advise your committee in this last-named particular and as the administration of national forests is under the jurisdiction of the Secretary of Agriculture, I would suggest a reference of the bill to him for specific information as to the area necessary for the proposed protection of the water supply of these cities and for such other recommendations as he may deem proper.

The bill should be amended by adding on page 1, line 3 , after the word "That" a comma and the words "for the conservation and protection of the water supplies of the cities of Corvallis, Dallas, and Oregon City, Oregon," so as to indicate the purpose for which the reservation is made. The word "Forest" in line 1 of the title of the bill should be changed to "Forests," and on page 2 , line 9 theref a comma should be insertea between the words "quarter" and "southwest," so as to properly describe the lands to be reserved in sec. 15 , T. 5 S., R, 4 E., Oregon.

As amended as herein indicated, the bill meets with my approval.

Cordially, yours,

F. K. LANE, Secretary.

August 13, 1919.

Hon. N. J. SinNotT

Chairman Committee on the Public Lands, House of Representatives.

Dear Mr. Sinnott: Reference is made to your request for a report upon the bill (H. R. 8028) to reserve as parts of the Oregon, Siuslaw, and Crater National Forests in Oregon certain lands that were revested in the United States pursuant to the decision of the Supreme Court of the United States in the case of the Oregon \& California Railroad Co. against the United States. 
The records of the Forest Service indicate that lands proposed for addition to the Oregon National Forest (one-third of which lie within the present forest boundary on Clackamas River drainage) are in the main rough and rugged mountains, well covered with timber, and of the general type best suited for national forest purposes, including watershed protection. The timber estimate for the entire area proposed to be added to the forest is $206,000,000$ feet $\mathrm{b} . \mathrm{m}$. The area is 5,720 acres.

The lands proposed to be added to the Siuslaw National Forest are mountainous lands, chiefly valuable for the production of timber and the protection and conservation of streamflows. The lands lying in township 7 south, range 6 west, are on the drainage of the Rickreal River which runs through the town of Dallas. The lands in township 12 south, range 7 west, are on the north and east slopes of Marys Peak, which is the highest point in the Coast Range Mountains. The estimated total stand of timber on these lands is $114,120,000$ feet $\mathrm{b} . \mathrm{m}$. The area is 2,400 acres.

The records of the Forest Service show that the E. $\frac{1}{2}$ of sec. 19 , and E. $\frac{1}{2}$ W. $\frac{1}{2}$ and $E . \frac{1}{2}$ of sec. 21, all in T. 39 S., R. 1 E., Willamette meridian, are parts of the watershed of Ashland Creek, which flows through the town of Ashland, and upon which the municipality depends for water and electric power. The Forest Service has already entered into an agreement with the city whereby the lands on Ashland Creek which are now within the national forest will be administered with a view to protecting the watershed from pollution so as to keep pure the water needed by the municipality. This agreement regulates the kind of timber which may be cut and prohibits the grazing of live stock within the present forest area. During the summer of 1914 a drift fence was constructed by a local live-stock association, in cooperation with the city of Ashland, along the ridge at the head of Ashland Creek, to prevent cattle drifting onto the watershed. One of the principal reasons why grazing is prohibited on the lands now within the forest is that considerable water hemlock grows on these lands. This weed is poisonous to cattle, and after eating it many have died, and their bodies, remaining upon the watershed, contaminated this all-important stream.

It is noted that the conduit for the city water supply traverses section 21 , which is proposed to be added, and that section 19 , the other addition, is the head of the drainage of one of the small creeks which flow into Ashland Creek. In response to a telegram sent the local forest officers, a report has been received that these areas have been classified by the Interior Department under the act of June 9, 1916, and that the officers making that classification describe the land as rough and mountainous and covered with brush and second-growth timber. The E. $\frac{1}{2}$ of sec. 19 contains $3,500,000$ feet $\mathrm{b} . \mathrm{m}$. of timber, and the E. $\frac{1}{2}$ and $\mathrm{E} \cdot \frac{1}{2} \mathrm{~W} . \frac{1}{3}$ of sec. 21 are reported as supporting $1,800,000$ feet of low -grade timber. These two tracts adjoin a part of the existing national forest which, as shown above, is maintained and administered largely with a view toward watershed protection for the benefit of the people of Ashland. These lands are of the same general character and are chiefly valuable for administration as a part of the Crater National Forest, particularly the protection of the Ashland watershed.

Section 2 of the bill indicates that the principal purpose of reserving these lands as a part of the national forests is for watershed protection of the municipalities named. To insure that protection, certain restrictions are provided regarding the sale of timber from the lands described in section 1.

In the opinion of this department, however, it is believed that the bill should be more elastic in regard to disposition of timber, so that it could be disposed of under the usual regulations prescribed for sales and free use from other national-forest lands which have proven satisfactory to other municipal officials. These would permit of a more equitable method of handling the timber for the benefit of the local settlers and other forest users, if it is found that the timber may be cut without impairing the watershed values, since under the act of June 4, 1897 (30 Stat., 11, 35), sales up to $\$ 100$ stumpage value may be made without advertisement, and free use may be allowed settlers and others for firewood, fencing, buildings, mining, prospecting, and other domestic uses. Also under the act of August 10, 1912 (37 Stat., 269), mature, dead, and down timber may be sold at actual cost to homestead settlers and farmers for their domestic use. These Forest Service regulations have heretofore proven adequate upon watersheds needed by other municipalities, and would no doubt be just as effective on these lands.

For that reason it is suggested that the following amendments be made to section 2 : Strike out the word "sale," in line 18, and substitute the word "cut." Strike out of line 21 the words "sell and," and also the phrase "to the highest bidder."

This department has had considerable experience in the administration of lands on watersheds needed by municipalities. At the present time more than 1,200 cities and towns obtain water from watersheds within national forests. Many of such municipalities have entered into cooperative agreements with the Forest Service. 
It is believed, therefore, that with the amendments suggested above the bill would be entirely workable and would accomplish what is desired by the municipal officials of Corvallis, Dallas, Oregon City, and Ashland.

For these reasons the department recommends favorable consideration of the measure with the proposed amendments.

Very truly, yours,

D. F. Houston, Secretary.

OCTOBER $30,1918$.

\section{Hon. SCOTT FERris,}

House of Representatives.

DEAR Mr. FerRIS: Receipt is acknowledged of your request for a report upon the bill (H. R. 12770) to reserve as part of the Oregon and Siuslaw National Forests in Oregon certain lands that were revested in the United States pursuant to the decision of the Supreme Court of the United States in the case of the Oregon \& California Railroad Co. $v$. The United States, together with such suggestions as this department may desire to make.

Section 1 of this bill is intended to add to the Oregon National Forest and the Siuslaw National Forest, in Oregon, certain lands that were revested in the United States pursuant to the decision of the Supreme Court of the United States in the case of the Oregon \& California Railroad Co. v. The United States.

Referring to the tracts proposed for addition to the Oregon National Forest (onethird of which lie within the present forest boundary, on Clackamas River drainage), the records of this office indicate that these lands are in the main rough and rugged mountains, well covered with timber, and of the general type best suited for national forest purposes, including watershed protection. The timber estimate for the entire area proposed to be added to the Oregon Forest is $206,000,000$ feet board measure. The area is 5,720 acres.

For the purpose of making the land description clear, it is suggested that two commas be inserted in the ninth line of page 2 of this bill, causing it to read as follows: "north half southeast quarter, southwest quarter, and north."

In regard to the lands proposed to be added to the Siuslaw National Forest, it appears that all of them are mountainous lands, chiefly valuable for the production of timber and the protection and conservation of stream flows. The lands lying in township 7 south, range 6 west, are on the drainage of the Rickreall River which runs through the town of Dallas. The lands in township 12 south, range 7 west, are on the north and east slopes of Marys Peak, which is the highest point in the Coast Range Mountains. The estimated total stand of timber on these lands is $114,120,000$ feet $\mathrm{b}$. $\mathrm{m}$. The area is 2,400 acres.

Section 2 of the bill indicates that the principal purpose of reserving these lands as a part of the national forests is for watershed protection for the municipalities of Corvallis, Dallas, and Oregon City, in the State of Oregon. To insure that protection, certain restrictions are provided regarding the sale of timber from the lands described in section 1 .

In the opinion of this department, however, it is believed that the bill should be more elastic in regard to disposition of the timber, so that it could be disposed of under the usual regulations prescribed for sales and free use from other national forest lands. These would permit of a more equitable method of handling the timber for the benefit of the local settlers and forest users, since under the act of June 4, 1897 (30 Stat., $11,35)$, sales up to $\$ 100$ stumpage value may be made without advertisement and free use may be allowed settlers and others for firewood, fencing, buildings, mining, prospecting, and other domestic purposes. Also under the act of August 10, 1912 (37 Stat., 269), mature, dead, and down timber may be sold at actual cost to homestead settlers and farmers for their domestic use. Forest Service regulations have heretofore proven ample upon watersheds needed by other municipalities and would no doubt be just as effective on these lands. For that reason it is suggested that section 2 be amended by striking out in lines 10 and 11 on page 3 the phrase "to the highest bidder," and by inserting after the word "hereof" in line 12 of page 3 the following: "in accordance with the regulations of the Secretary of Agriculture for the national forests."

It is also suggested that the word "such" in line 13 be stricken out and the word "any" substituted in lieu thereof, and that the word "thereof" be inserted after the word "s "le" in the same line.

This department has had considerable experience in the administration of lands on watersheds needed by municipalities, and believes that with the amendments suggested above the bill would be entirely workable and would accomplish what is 
desired by the municipal officials of Corvallis, Dallas, and Oregon City. For these reasons the department asks your favorable consideration of the measure with the proposed amendments.

Very truly, yours,

G. I. Christin,

Acting Secretary Department of Agriculture.

Hon. SCOTT FERRIS,

February 3, 1919.

Chairman Committee on the Public Lands, House of Representatives.

Dear Mr. Ferris: Receipt is acknowledged of a copy of the bill H. R. 11550, which proposes to add to the (rater National Forest in Oregon, certain lands formerly a part of the grant to the Oregon of California Railroad ('o., lut revested in the Linited States in accordance with a decision of the Supreme Court of the United States.

The lands affected by the bill are described as follows: E. $\frac{1}{2}$ sec. 19 and E. $\frac{1}{2}$ IV. $\frac{1}{2}$ and E. $\frac{1}{2}$ of sec. 21, all in T. 39 S., R. 1 E., Willamette meridian. The records of the Forest Service show that these lands are a part of the watershed of Ashland Creek, which flows throngh the town of Ashland, and npon which the municipality is depending for water and electric power. The Forest Service has already entered into an agreement with the city whereby the lands on Ashland Creek which are now within the national forest will be administered with a view to protecting the watershed from pollution so as to keep pure the water needed by the municipality. This arreement regulates the kind of timber which may be cut and prohibits the grazing of live stock within the present forest area. During the summer of 1914 a drift fence was constructed by a local live-stock association, in cooperation with the city of Ashland, along the ridge at the head of $\Lambda$ shland (reek, to prevent cattle drifting onto the watershed. One of the principal reasons why grazing is prohibited on the lands now within the forest is that considerable water hemlock grows on these lands. This weed is poisonous to cattle, and many after eating it have died, and their bodies remaining upon the watershed contaminated this all-important stream.

By reference to the map it is noted that the conduit for the city water supply traverses section 21, which is proposed to be added, and that section 19, the other addition, is the head of the drainage of one of the small creeks which flow into Ashland Creek. In response to a telegram sent the local forest officers, a report has been received that these areas have been classified by the Interior Department under the act of June 9, 1916, and that the uflicers making that classification describe the land as rough and mountainous and covered with brush and second-growth timber. The E. $\frac{1}{2}$ sec. 19 contains $3,500,000$ feet, board measure, of timber, and the E. $\frac{1}{3}$ and $\mathrm{E} . \frac{1}{2}$ W. $\frac{1}{2}$ of sec, 21 are reported as supporting $1,800,000$ feet of low-grade timber. These two tracts adjoin a part of the existing national forest, which, as shown above, is maintained and administered largely with a view toward watershed protection for the benefit of the people of Ashland. These lands are of the same general character and are chiefly valuable for administration as a part of the Crater National Forest, particularly the protection of the Ashland watershed. Fu these reasons this department recommends favorable consideration of this measure.

Very truly, yours,

\section{V: Marvin, Acting Secretary.}

The water commission of Corvallis and the city comeil of the same city have agreed in the documents printed below to provide for the protection of the areas which will be transfered for the protection of the water supply of Corvallis at its own axpense. It is understoor that the other cities will do likewiso.

Whereas a bill is about to be introduced in Congress to set aside as a reserve for the protection of the water supply of the city of Corvallis, Oreg., certain portions of the Oregon \& California grant lands in the watershed of Rock Creek, from which the water supply of the city of Corvallis is obtained, and

Whereas it is vital to the interests of the city of Corvallis, and to the maintenance of the water supply of said city, that the said lands and timber be preserved in their present condition and protected from fires and other depredations: Therefore be it,

Resolved by the water commission of said city of Corvallis, in event such lands are set aside by act of Congress as a reserve for the protection of the water supply of said city of Corvallis, That an adequate patrol be maintained on the said lands during the dry season of the year, to the end that fires, and other lepredatinns in such reserve may be prevented and that the expense of such patrol be defrayed by the said water commission. 
Resolved, That a copr of this resolution be incorporated in the minutes of the water commission of the city of Corvallis, that a copy hereof he furnished to the city council of the city of Corvallis, and that a copy hereof be furnished to the Congress of the United States through Representative W. C. Hawley.

I, J. W. Foster, clerk of the water commission of the city of Corvallis, hereby certify that the foregoing is a true copy of a resolution adopted at a regular meeting of the said water commission of the city of Corvallis, on the 7th day of April, 1919, all of the members of said water commission being present.

[SEAL.]

J. W. Foster,

Clerk of Water Commission of the city of Corvallis, Oreg.

Whereas the water commission of the city of Corvallis has, on this date, passed the foregoing resolution;

Whereas a bill is about to be introduced in Congress to set aside as a reserve for the protection of the water supply of the city of Corvallis, Oreg., certain portions of the Oregon \& California grant lands in the watershed of Rock Creek, from which the water supply of the city of Corvallis is obtained; and

Whereas it is vital to the interests of the city of Corvallis, and to the maintenance of the water supply of said city, that the said lands and timber be preserved in their present condition and protected from fires and other depredations: Therefore be it

Resolved by the water commission of said city of Corvallis, in event such lands are set aside by act of Congress as a reserice for the protection of the water supply of said city of Corvallis, That an adequate patrol be maintained on the said lands during the dry season of the year, to the end that fires and other depredations in such reserve may be prevented, and that the expense of such patrol be defrayed by the said water commission.

Resolved, That a copy of this resolution be incorporated in the minutes of the water commission of the city of Corvallis, that a copy hereof be furnished to the city council of the city of Corvallis, and that a copy hereof be furnished to the Congress of the United States through Representative W. C. Hawley.

Whereas it is the opinion of this council that if said timber is so set aside into a reserve, as recited in said resolution, the same should be patrolled and the cost thereof borne by the city of Corvallis: Therefore be it

Resolved, That this council hereby indorse the foregoing resolution and ratify and approve the same.

\section{State of Oregon,}

County of Benton, City of Corvallis, ss:

I, A. T. Grugett, municipal judge of the city of Corvallis, Benton County, Oreg., and ex-officio clerk of the council of said city, do herehy certify that the foregoing is a true and correct copy of a resolution duly adopted by the council of said city at a regularly adiourned meeting of said council held A pril \$, 1919, and that I am the legal custodian of the original record thereof.

In testimony whereof I have hereunto set my hand and the seal of said city this April 12, 1919.

[SEAL.]

A. T. GrugetT, Municipal Judge.

Dean George W. Peary, of the school of forestry, Oregon State Agricultural College, makes the following statement of the importance of the proposed legislation to the city of Corvallis:

Oregon State Agricultural College, Corvallis, Oreg., October 26, 1918.

Hon. W. C. Hawley, M. C., Washington, D.C.

My Dear Mr. Hawlex: Mr. E. E. Wilson has called my attention to H. R. 12770 and to the letter of the Secretary of the Interior referring thereto. As you know from a conversation we had when I had the pleasure of meeting you during a recent visit to Corvallis, I am intensely interested in the Corvallis watershed. I am intimately acquainted with every acre of forested land on the watershed since I have marle a very detailed examination of the timber thereon and of the land itself with reference to its utility as a city watershed. I am fimly convinced that every acre 
of land described in H. R. 12770 as situated in T. 12 S., R. 7 W., sec. 15, S. $\frac{1}{2}$, SW. $\frac{1}{2}$, NW. $\frac{1}{4}, \mathrm{SW} . \frac{1}{4}, \mathrm{SW} . \frac{1}{4}$, SE. $\frac{1}{4}$; sec. 21 , SE. $\frac{1}{4}, \mathrm{~N} . \frac{1}{2} ;$ sec. 23 , SW. $\frac{1}{4}, \mathrm{NW} \cdot \frac{1}{4}, \dot{W}^{2} \cdot \frac{1}{2}, \mathrm{SW} \cdot$ $\frac{1}{4}$; sec. 27 , all; sec. 35, N. $\frac{1}{2}$; is absolutely essential to the maintenance of the domestic water supply of the city of Corvallis.

It may be assumed that I am qualified to judge concerning the factors which are essential to a city water supply derived from a forested watershed since I was educated as a professional forester and was employed in the Federal Forest Service for five years during which time the major portion of my work was on watershed projects. in the State of California. For the past 10 years I have been at the head of the school of forestry in the Oregon State College and have, of course, been constantly in touch with watershed problems during that time.

I sincerely trust that through your efforts Congress may grant to the city of Corvallis lands above described in order that the quality and amount of our present water supply may not be impaired.

Yours, very sincerely,

Geo. W. PeAvy, Dean School of Forestry. 

Gaylord Bros.

Makers

Syracuse, N. Y. PAI. JAN. 2I, 1908 
LIBRARY OF CONGRESS

||||||||||||||||||||||||||||||||||||||||||||||| |||||||||||||||||||||||||||||||||||||||||||||||||||

00008977?07 